\title{
ANGKA KEJADIAN INSOMNIA PADA LANSIA DI PANTI TRESNA WERDHA WANA SERAYA DENPASAR, BALI TAHUN 2015 Dania Danirmala $^{1}$, Putri Ariani ${ }^{2}$
}

\author{
${ }^{1}$ Program Studi Pendidikan Dokter Fakultas Kedokteran Universitas Udayana \\ ${ }^{2}$ Bagian Ilmu Kedokteran Jiwa Fakultas Kedokteran Universitas Udayana \\ Email : daniagunarsa@gmail.com
}

\begin{abstract}
ABSTRAK
Insomnia merupakan penyakit yang sangat berisiko dapat terjadi pada orang usia lanjut. Dimana prevalensi insomnia sendiri cenderung makin meningkat pada lansia, hal ini juga berhubungan dengan bertambahnya usia dan adanya berbagai penyebab lainnya. Penelitian ini bertujuan untuk mengetahui angka kejadian insomnia pada lansia di Panti Tresna Werdha Wana Seraya Denpasar, Bali Tahun 2015 yang dilihat berdasarkan usia, jenis kelamin, gangguan kondisi medis dan status pernikahan. Penelitian ini dilakukan menggunakan jenis penelitian deskriptif dengan rancangan cross-sectional dan metode pengambilan sampel yang digunakan adalah total sampling, dimana sampel penelitian ini berjumlah 40 orang. Data penelitian ini diambil dengan menggunakan pengisian dari kuesioner Insomnia Rating Scale. Hasil dari penelitian ini didapatkan $70 \%$ lansia mengalami insomnia. Angka kejadian insomnia pada lansia tahun 2015 ditempat dilaksanakannya penelitian ini termasuk cukup tinggi sehingga diperlukannya analisis lebih lanjut dan mendalam mengenai hal yang menyebabkan tingginya angka kejadian insomnia pada lansia, karena insomnia sendiri dapat mengganggu lansia dalam menikmati hari tuanya.
\end{abstract}

Kata kunci : insomnia, lansia, panti sosial

\begin{abstract}
Insomnia is one of the diseases that are particularly at high risk can occur in elderly. Where the prevalence of insomnia itself tends to increase in the elderly, it is also associated with age and the presence of various other causes. This study aimed to determine the prevalence of insomnia in the elderly in social institution Tresna Werdha Wana Seraya Denpasar, Bali in 2015 were seen based on age, sex, medical condition disorders and marital status. The type of this research was descriptive study with cross sectional design and the sampling method used was total sampling, sample of this study were about 40 people. The research data was taken using a questionnaire Insomnia Rating Scale. Results of this study found $70 \%$ of elderly experience insomnia. The incidence of insomnia in the elderly in society, particularly in social institution Tresna Werdha Wana Seraya Denpasar, Bali 2015 is quite high so we need a deeper analysis of the causes of the high incidence of insomnia in the elderly because insomnia can distrub the elderly to enjoy old age.
\end{abstract}

Keywords : insomnia, elderly, social institution

\section{PENDAHULUAN}

Salah satu gangguan tidur yang sering terjadi dan paling dikenal oleh masyarakat adalah insomnia. Dimana insomnia merupakan kesulitan dalam memulai atau mempertahankan tidur $^{1}$.
Dimana kurang lebih $60 \%$ lansia di Indonesia dilaporkan mengalami insomnia ${ }^{2}$. Saat ini usia harapan hidup penduduk di Indonesia semakin tinggi, dan dengan semakin meningkatnya usia harapan hidup 
maka lebih besar kemungkinan untuk terjadinya suatu penyakit pada lansia ${ }^{4}$.

Pada orang-orang dengan usia lanjut, kondisi kualitas tidur di malam hari akan terjadi pengurangan dibandingkan dengan orang dewasa. Pada orang yang berusia 70 tahun didapatkan $22 \%$ memiliki keluhan mengenai masalah tidur dan $30 \%$ dari usia tersebut juga mengalami terbangun pada malam hari ${ }^{5}$. Prevalensi insomnia sendiri cenderung makin meningkat pada lansia, hal ini juga berhubungan dengan

\section{BAHAN DAN METODE}

Penelitian ini menggunakan rancangan deskriptif cross sectional noneksperimental terhadap penderita insomnia pada orang-orang lansia dengan pengambilan data secara langsung melalui wawancara dengan menggunakan media berupa kuesioner yang dimulai pada bulan April sampai Mei 2015. Subjek penelitian ini diambil secara total sampling sehingga seluruh lansia yang memenuhi kriteria inklusi dapat menjadi responden, yaitu berjumlah 40 orang. Kriteria inklusi penelitian ini adalah lansia wanita dan lakilaki yang berusia 60 sampai lebih dari 90 tahun, masih memiliki kemampuan kognitif yang baik, merupakan penghuni dari Panti Tresna Werdha Wana Seraya Denpasar, Bali dan bersedia menjadi responden dalam penelitian ini dan mengikuti prosedurprosedur penelitian. Lansia yang telah mengisi lembar persetujuan responden selanjutnya akan diwawancara menggunakan kuesioner.

Penelitian ini menggunakan kuesioner karakteristik responden dan juga kuesioner Insomnia Rating Scale yang sebelumnya sudah dikembangkan oleh

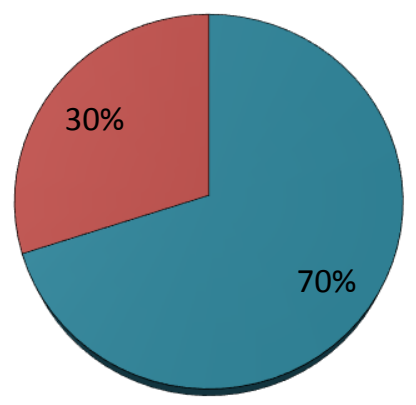

bertambahnya usia dan adanya berbagai penyebab lainnya ${ }^{6}$.

Berdasarkan perkiraan dari jumlah kasus gangguan tidur insomnia yang semakin meningkat terjadi di kalangan lansia, maka penelitian ini bertujuan untuk mengetahui angka kejadian dari insomnia pada lansia yang saat ini tinggal di Panti Tresna Werdha Wana Seraya Denpasar, Bali pada tahun 2015.

Kelompok Studi Biologik Psikiatri Jakarta (KSBPJ). Kuesioner karakteristik responden terdiri dari 8 pertanyaan untuk mengetahui identitas dan faktor-faktor yang dapat mempengaruhi insomnia pada lansia. Kuesioner Insomnia Rating Scale terdiri dari 8 pertanyaan dengan jumlah skor maksimum adalah 24 dan dikatakan insomnia bila skor telah melebihi 10. Instrumen yang digunakan telah teruji realibilitas, sensitifitas dan spesifitasnya dengan hasil yang baik ${ }^{7}$.

Data yang didapat diolah menggunakan software dengan program SPSS 17.0, lalu dianalisa dengan cara deskriptif dan ditampilkan berbentuk tabel distribusi frekuensi untuk memperlihatkan angka kejadian insomnia pada lansia dan variabel-variabel yang mempengaruhinya, yaitu usia, jenis kelamin, gangguan kondisi medis yang mendasari dan status pernikahan.

\section{HASIL}

Jumlah Angka Kejadian Insomnia pada Lansia

Pada 40 orang responden, didapatkan 28 orang $(70 \%)$ mengalami insomnia dan 12 orang $(30 \%)$ tidak mengalami insomnia (Gambar 1).

Gambar 1. Jumlah Angka Kejadian Insomnia dan Tidak Insomnia pada Lansia di tahun 2015

\section{Karakteristik Subjek Penelitian}

Berdasarkan kelompok usia dalam penelitian ini, didapatkan $47,5 \%$ responden berusia 75-90 tahun. Sedangkan, bila dilihat dari jenis kelamin maka $75 \%$ responden merupakan perempuan dan $25 \%$ laki-laki. Pada keseluruhan responden, sebesar $90 \%$ mengalami gangguan kondisi medis dan bila 
dilihat pada variabel status pernikahan, $80 \%$ responden berstatus janda atau duda. Total dari keseluruhan responden didapatkan $30 \%$ tidak mengalami insomnia dan $70 \%$ responden mengalami insomnia.

Tabel 1. Gambaran Karakteristik Demografi Responden

\begin{tabular}{|c|c|c|}
\hline Yariabel. & Frekuensi (f) & Persentase (\%) \\
\hline \multicolumn{3}{|l|}{ Usia } \\
\hline - $60-74$ & 17 & 42,5 \\
\hline - $75-90$ & 19 & 47,5 \\
\hline - $>90$ & 4 & 10 \\
\hline \multicolumn{3}{|l|}{ Jenis, Kelamin. } \\
\hline - Laki-laki & 10 & 25 \\
\hline - Perempuan & 30 & 75 \\
\hline \multicolumn{3}{|l|}{ Gangeuan KondisidAedis. } \\
\hline - Ada & 36 & 90 \\
\hline - Tidak ada & 4 & 10 \\
\hline \multicolumn{3}{|l|}{ Status Pernilcahan } \\
\hline - Menikah & 3 & 7,5 \\
\hline - Janda/Duda & 32 & so \\
\hline - Tidak Menikah & 5 & 12,5 \\
\hline \multicolumn{3}{|l|}{ Status Insomnia } \\
\hline - Tidak Insomnia & 12 & 30 \\
\hline - Insomnia & 28 & 70 \\
\hline
\end{tabular}

\section{Angka Kejadian Insomnia Berdasarkan Karakteristik Responden}

Berdasarkan kelompok usia didapatkan lansia yang mengalami insomnia di tempat dilakukannya penelitian adalah semua lansia yang berumur lebih dari 90 tahun mengalami insomnia. Sedangkan, pada kelompok usia 60-74 tahun hanya sebesar $76,5 \%$ yang mengalami insomnia dan kejadian insomnia lebih rendah pada kelompok usia 75-90 tahun, yaitu hanya $57,9 \%$.

Pada penelitian terhadap lansia, di Panti Sosial ini pada tahun 2015 didapatkan bahwa lansia laki-laki lebih banyak yang mengalami insomnia, yaitu sebesar $80 \%$ dibandingkan dengan jenis kelamin perempuan yang hanya sebesar $66,7 \%$.

Sedangkan, pada lansia yang mengalami gangguan kondisi medis cenderung mengalami insomnia, yaitu sebesar $75 \%$ daripada yang tidak memiliki gangguan kondisi medis yang hanya sebesar $25 \%$.

Sesuai dengan penelitian terhadap lansia yang berada di Panti ini berdasarkan status pernikahan, kejadian insomnia lebih banyak terjadi pada lansia yang tidak menikah, yaitu sebesar $80 \%$. 
Tabel 2. Angka Kejadian Status Insomnia Berdasarkan Usia, Jenis Kelamin, Gangguan Kondisi Medis dan Status Pernikahan Yariabel Status Insomnia

Insomnia

Tidak Insomnia (\%)

\begin{tabular}{ccc}
\hline Usia & & \\
- $60-74$ & $4(23,5)$ & $13(76,5)$ \\
- $75-90$ & $8(42,1)$ & $11(57,9)$ \\
Jenis Kelamin & $0(0)$ & $4(100)$ \\
- Iaki-laki & & \\
- Perempuan & $2(20)$ & $8(80)$ \\
Gangguan Kondisi Medis & $10(33,3)$ & $20(66,7)$ \\
- Ada & & $27(75)$ \\
Status Pernikahan & $9(25)$ & $1(25)$ \\
- Menikah & $3(75)$ & $1(33,3)$ \\
- Tanda/Duda & & $23(71,9)$ \\
\hline
\end{tabular}

\section{PEMBAHASAN}

Berdasarkan hasil penelitian ini, didapatkan karateristik usia pada orangorang lanjut usia di Panti ini tahun 2015 adalah semua lansia pada kelompok usia lebih dari 90 tahun mengalami insomnia. Dimana dalam sebuah penelitian yang dilakukan pada 5886 orang tua berusia 65 tahun ke atas juga ditemukan bahwa lebih dari $70 \%$ diantaranya mengalami insomnia ${ }^{6}$. Menurut Sri Adiyati, juga menyatakan, semakin bertambahnya usia seseorang maka akan menyebabkan berkurangnya efektifitas dari tidur, yaitu $70 \%$ hingga $80 \%$. Didapatkan juga bahwa kejadian insomnia lebih tinggi dialami oleh usia yang lebih tua, dimana orang lebih tua juga akan lebih berisiko mengalami gangguan sulit tidur yang serius ${ }^{3}$. Zainul juga menyatakan bahwa 40-50\% dari populasi lansia menderita gangguan tidur ${ }^{8}$. Hal ini juga sesuai dengan pernyataan Taat $\mathrm{dkk}^{5}$, yaitu faktor usia merupakan faktor yang sangat mempengaruhi kualitas tidur seseorang. Dimana, efektifitas saat tidur akan semakin berkurang dengan bertambahnya usia.

Pada karateristik jenis kelamin lansia di tempat penelitian diketahui bahwa seperti yang tercantum pada Tabel 2, jenis kelamin terbanyak yang mengalami insomnia merupakan laki-laki yang berjumlah 8 orang $(80 \%)$ dan perempuan 20 orang $(66,7 \%)$. Pada hasil penelitian analisis univariat yang dilakukan oleh Ida, didapatkan juga bahwa prevalensi insomnia pada responden laki-laki lebih besar yaitu
$57,7 \%$ dibandingkan dengan jenis kelamin perempuan yang hanya sebesar $48,6 \% 9$. Taat $\mathrm{dkk}^{5}$ juga mengatakan jika responden lakilaki lebih mudah mengalami terbangun di malam hari. Dimana lansia mudah terbangun dari tidur karena pengaruh stimulasi internal maupun eksternal dan hal ini kebanyakan terjadi pada laki-laki dibandingkan perempuan. Namun, Michael \& Peter mengatakan bahwa risiko insomnia ditemukan lebih tinggi terjadi pada perempuan daripada laki-laki ${ }^{10}$. Dalam hasil penelitiannya Leonardi juga mengatakan hal yang sama, yaitu perempuan lebih banyak mengalami insomnia ${ }^{11}$. Terdapat perbedaan dengan hasil penelitian ini, dimana laki-laki didapatkan lebih banyak mengalami insomnia, hal ini dimungkinkan karena adanya perbedaan jumlah responden antara lansia laki-laki dan perempuan pada penelitian ini.

Berdasarkan gangguan kondisi medis, pada penelitian ini ditemukan bahwa lansia yang mengalami gangguan kondisi medis cenderung akan mengalami insomnia daripada yang tidak mengalami gangguan kondisi medis, yaitu sebesar $75 \%$. Made Gede Cahyadi juga mengatakan bahwa secara teori, status kesehatan seseorang memang telah diprediksi memiliki hubungan yang erat dengan insomnia. Gangguan kondisi medis seringkali menjadi komorbid dari gangguan tidur insomnia ${ }^{12}$. Hal ini juga sesuai dengan pernyataan Sharon $\mathrm{dkk}^{13}$ bahwa seseorang yang memiliki gangguan kondisi medis dan psikiatri akan secara 
khusus meningkatkan resiko dari terjadinya insomnia, 50-70\% orang yang memiliki gangguan nyeri kronis juga mengalami insomnia.

Apabila dilihat berdasarkan status pernikahan, didapatkan bahwa lansia yang mengalami insomnia di tempat ini lebih banyak terjadi pada lansia yang tidak menikah, yaitu sebesar $80 \%$. Dalam penelitian oleh Kim $\mathrm{dkk}^{14}$ mendapatkan bahwa responden yang tidak memiliki pasangan hidup secara signifikan lebih banyak dilaporkan mengalami insomnia. Banyak juga penelitian yang telah mengatakan terdapat hubungan yang erat antara tidak menikah, janda atau duda, maupun bercerai dengan gangguan tidur insomnia pada lansia. Dikatakan pada populasi tersebut akan lebih berisiko untuk mengalami kebiasaan tidur yang buruk, seperti jam tidur yang tidak teratur daripada lansia yang masih memiliki pasangan hidup. Ida juga mendapatkan pada penelitian yang telah Ia lakukan, bahwa orang yang tidak menikah mengalami insomnia lebih tinggi, yaitu sebesar $63,6 \%$ dibandingkan hanya $53,7 \%$ pada orang yang berstatus menikah ${ }^{9}$. Hal yang sama juga dinyatakan oleh Made Gede Cahyadi dimana orang yang telah

\section{DAFTAR PUSTAKA}

1. Kaplan Harold I., Sadock Benjamin J., Grebb Jack A. Kaplan - Sadock, Sinopsis Psikiatri - Ilmu Pengetahuan Perilaku Psikiatri Klinis; alih bahasa, Kusuma Widjaja; editor, Wiguna I Made. Edisi 7, Jilid 2, Jakarta: Binarupa Aksara. 2010.h.200-205.

2. Tommy Kurniawan. Faktor-Faktor yang Mempengaruhi Gangguan Tidur (Insomnia) Pada Lansia di Panti Tresna Werdha Kabupaten Magetan. Fakultas Ilmu Kesehatan Universitas Muhammadiyah Ponorogo. 2012.

3. Sri Adiyati. Pengaruh Aroma Terapi Terhadap Insomnia Pada Lansia di PSTW Unit Budi Luhur Kasongan Bantul Yogyakarta. Jurnal Kebidanan, 2010;2:2.

4. Marchira Carla R., Wirasto Ronny T., DW Sumarni. Pengaruh FaktorFaktor Psikososial dan Insomnia Terhadap Depresi Pada Lansia di Kota Yogyakarta. Berita Kedokteran Masyarakat, 2007;23:1.

5. Taat Sumedi, Wahyudi, Ani Kuswati. Pengaruh Senam Lansia menikah cenderung lebih sedikit yang mengeluh mengalami gangguan tidur insomnia dibandingkan orang yang tidak menikah $^{12}$.

\section{SIMPULAN}

Berdasarkan hasil penelitian dan pembahasan, angka kejadian insomnia pada lansia di tempat penelitian ini tahun 2015 adalah 28 orang $(70 \%)$, dengan total lansia yang berada di panti tersebut adalah 40 orang. Didapatkan bahwa semua lansia yang berusia lebih dari 90 tahun mengalami insomnia. Jenis kelamin yang paling banyak ditemukan mengalami insomnia adalah lakilaki, yaitu sebanyak $80 \%$

dan pada perempuan didapatkan $66,7 \%$. Pada lansia yang mengalami gangguan kondisi medis didapatkan lebih besar, yaitu $75 \%$ dibandingkan yang tidak mengalami gangguan kondisi medis yang hanya sebesar $25 \%$. Lalu pada variabel status pernikahan dari lansia didapatkan bahwa lansia yang tidak menikah lebih banyak mengalami insomnia dibandingkan yang lainnya, yaitu sebanyak $80 \%$.

Terhadap Penurunan Skala Insomnia Pada Lansia di Panti Wredha Dewanata Cilacap. Jurnal Keperawatan Soedirman, 2010;5:1.

6. Ayu Winda Bestari. Penerimaan Masa Lalu Terhadap Insomnia Pada Lansia. Jurnal Online Psikologi, 2013;1:2

7. Aditya Ericha Raharja. Hubungan Antara Tingkat Depresi Dengan Kejadian Insomnia Pada Lanjut Usia di Karang Werdha Semeru Jaya Kecamatan Sumbersari Kabupaten Jember. Universitas Jember. 2013.

8. Zainul Anwar. Penanganan Gangguan Tidur Pada Lansia. Fakultas Psikologi Universitas Muhammadiyah Malang. 2010.

9. Ida Rosdiana. Analisis Faktor Yang Berhubungan Dengan Kejadian Insomnia Pada Pasien Gagal Ginjal Kronik Yang Menjalani Hemodialisis Di Rumah Sakit Umum Daerah Kota Tasikmalaya Dan Garut. Universitas Indonesia Depok. 2011. 
10. Sateia Michael J. \& Nowell Peter D. Insomnia. The Lancet,2004; 364 : 1959-73.

11. Leonardi A. Goenawan. Referat Ilmu Kesehatan Jiwa dan Perilaku: Insomnia, Rumah Sakit Dharmasakti. Fakultas Kedokteran Universitas Katolik Indonesia Atmajaya. 2012.

12. Made Gede Cahyadi Permana. Insomnia Dan Hubungannya Terhadap Faktor Psikososial Pada Pelayanan Kesehatan Primer. Bagian Ilmu Kesehatan Jiwa Fakultas Kedokteran Universitas Udayana/Rumah Sakit Umum Pusat Sanglah. 2013.
13. Sharon Schutte Rodin., Lauren Broch., Daniel Buysse, dkk. Clinical Guideline for the Evaluation and Management of Chronic Insomnia in Adults. Journal of Clinical Sleep Medicine, 2008;4:5.

14. Kim Won-Hyoung., Kim ByungSoo., Kim Shyn-Kyum, dkk. Prevalence of Insomnia and Associated Factors in a Community Sample of Elderly Individuals in South Korea. International Psychogeriatric Association,2013; 25:10, 1729-1737. 